\title{
\#FeesMustFall and the decolonised university in South Africa: Tensions and opportunities in a globalising world
}

\author{
Dominic Griffiths \\ Division of Studies in Education, Wits School of Education, University of the Witwatersrand, Johannesburg, South Africa
}

\section{A R T I C L E I N F O}

\section{Keywords:}

\#FeesMustFall

Decolonisation

Global coloniality

South African higher education

Postcolony

\begin{abstract}
A B S T R A C T
Colonialism's legacy in South Africa includes persistent economic inequality which, since the country's universities charge fees, bars many from higher education, perpetuating the marginalisation of those previously disadvantaged by the apartheid regime. In 2015-6, country-wide unrest raged across university campuses, as students protested the yearly cycle of tuition increases under the slogan \#FeesMustFall, demanding "free, decolonised education". Protests ended in December 2017 when the government announced a sliding-scale payment policy alleviating the economic burden for poorer students. This paper sets the \#FMF movement and its twin demands within the context of decoloniality, and argues that while free education has been achieved, imagining and implementing decolonised education for South Africa in an increasingly globalised world is a more challenging, elusive goal.
\end{abstract}

\section{Introduction}

On the 1 July 2016, I joined the University of the Witwatersrand in Johannesburg, South Africa, as a lecturer in Philosophy of Education. By September the university was in a state of turmoil. Campuses had become war zones with strong security and police presence. Lectures were suspended until further notice, and we were on the precipice of not being able to complete the academic year, as violent protests and wilful destruction of university property gave way to arrests and constant confrontations between the police, security forces and protesting students demonstrating under the slogan \#FeesMustFall. This student movement, which demands "free decolonized education for black people" (SABC Digital News, 2016), began in 2015 when the South African treasury announced that university fees would increase by $10.5 \%$, putting a degree even further out of the reach of the country's largely black economically underprivileged majority. In response, striking students across the country brought universities to a close.

In this paper I want to theorise this crisis in South African higher education, and the local (but also global) intractability of it. The protests are indicative of broader questions of the supposed postcolonial transformation of African universities. Arguably \#FeesMustFall is a result of a failure by South African universities to act as a public, transformative good, but instead remain bastions of what the striking students perceive as white, European cultural and economic privilege. ${ }^{1}$ The higher education crisis is "intractable" because it is still unclear how to fundamentally change this situation. On the one hand it is evident that the eventual capitulation of then president Jacob Zuma to the students' demands in December 2017 achieved the issue of "free" education for many. On the other hand, the question of the "decolonisation" of the university itself, as an institutional and epistemic colonial relic, in an increasingly competitive, interconnected and unequal global world, remains to be solved.

Thus, in this paper, I argue that the government's response to \#FMF only addresses economic decolonisation. The fact that the

E-mail address: dominic.griffiths@wits.ac.za.

${ }^{1}$ See Rensburg (2017, pp. 20-1) for details of the South African university profile in relation to national demographics. 
protests ended suggests that in one sense the students' calls for decolonisation have less to do with wanting to undermine a dominant Western cultural ideology than with desperately needed economic emancipation - for access to those privileges enjoyed by whites during and beyond apartheid, most significantly affordable and relatively easy access to tertiary education, and the quality of life that it can ensure, a life defined by membership of global consumer society. I will begin with a brief historical overview of the \#FeesMustFall movement, and then move on to discuss the idea of economic and also epistemic decolonisation within the university context. ${ }^{2}$ Here I will draw on the notion of "global coloniality" developed by Ramon Grosfoguel, in tandem with Achille Mbembe's idea of the "postcolony". These ideas will be developed to support my concluding argument that \#FeesMustFall was essentially about economic emancipation, and that the epistemic decolonisation of the university, while remaining extremely difficult, is not wholly intractable, but rather offers some pragmatic avenues for action.

\section{2. \#FeesMustFall}

The South African university government subsidy had been in steady decline since 1994. The University of the Witwatersrand, for example, in 1994, had 70\% of its expenses covered by government subsidies, but by 2013 this had been reduced to around $30 \%{ }^{3}$ Declining subsides were thus made up by a yearly cycle of ongoing tuition increases. These increase cycles came to represent a concrete manifestation that post-apartheid South Africa, a supposedly free, equal and democratic country, had failed to improve the quality of life of many of its citizens by economically disbarring them from pursing tertiary education. Indeed a recent World Bank report indicates that South Africa has one of the highest inequality rates in the world (2018). Significantly most of the protesting students are part of the 'born-frees' - members of the generation of South Africans born after 1994, when political apartheid ended. ${ }^{4}$ Yet, many of these students remain beset by the same dire poverty that shaped the lives of their parents. The difference is that the generation of 'born-frees' expect, and were promised a better life, which has not eventuated. What further exacerbates this tension is the palpable evidence of continuing white economic privilege and white generational wealth, which has ensured continued white prosperity.

When \#FeesMustFall began in 2015 the South African government, lacking any decisive answer to the crisis, capitulated to student protest, by not raising fees, and hoped that this would placate the situation. In 2016 the government tried to hedge its bets by raising fees again, but capping the increase at $8 \%$, and making universities responsible for deciding, within the cap range, how much they would increase their fees by. It was during these student protests that erupted nationwide again, after this announced increase, that I took up my post at Wits. 2017 also saw sporadic strikes in the lead up to the June exams as universities anxiously awaited the release of the Heher Fees Commission Report (2017a). This report was commissioned by the presidency to determine the viability of free tertiary education in South Africa.

The comprehensive 752 page report was released in November 2017 and makes clear that "there is insufficient financial capacity in the state to provide totally free higher education and training to all who are unable to finance their own education, let alone to all students, whether in need or not" (Heher, 2017b, p. 3). The report recommends a "cost-sharing model" in the form of an "income contingent loan" scheme (Heher, 2017b, p. 4). Disregarding the report, the then president of South Africa, Jacob Zuma, who would only remain in office for another four months, announced in December 2017 that the government would fully subsidise free higher education for those students from households with a combined annual income of up to R350 000 per year (ca. $\$ 26,000$ US). ${ }^{5}$ Furthermore, in line with the Heher report President Zuma committed to increasing university subsides from $0.68 \%$ to $1 \%$ of the South African Gross Domestic Product over the next five years (Areff \& Derrick Spies, 2017). Since the protests the South African government has injected about $\$ 1.2$ billion US extra into the tertiary section (Staff, 2016). Furthermore, if the household income of a student is above R350 000 a sliding scale will determine how much the university fees will cost - essentially the more a household earns the more a student will be expected to pay in tuition.

The release of the report itself, in November 2017, may have been strategically delayed by a few months to allow universities to begin the November examination period, and thus avoid the previous disruptions that occurred during teaching time, which nearly derailed the academic year. It is likely that had Jacob Zuma not announced the implementation of free education, or some other

\footnotetext{
${ }^{2}$ The notion of epistemic declonisation emerges in the work of Walter Mignolo who critical interrogates euro-centric epistemologies and their illusory, constructed claims for the "idea of a universal knowledge", while concealing their own "geo-historical and bio-graphical locations" (2009, p. 160). His call for epistemic disobedience "means to delink from the illusion of the zero point epistemology" (2009, p. 160). See also Mignolo (2011).

${ }^{3}$ For figures on the gradual systematic underfunding of South African universities see Jansen (2017, pp. 28-9; 40-1).

${ }^{4}$ Jansen makes the important point that the 'protesting students' are not "one large amorphous mass of discontented students roaming across and disrupting university campuses" (2017, p. 106) but comprise numerous and shifting collectives.

${ }^{5}$ In spite of this magnanimous (and arguably ill-considered) announcement President Zuma had exhausted the patience of his party, the African National Congress (ANC). President of the Republic for about 9 years (since May 2009), he had managed to continually dodge accusations of rape, corruption, fraud, money-laundering and racketeering charges. Finally, the increasing revelations that he had colluded with a pair of powerful businessmen brothers, known colloquially by South Africans as 'the Guptas' in state capture and the unlawful awarding of government tenders, led to his forced resignation by his party in February 2018. The next South African general election is in 2019 and Jacob Zuma had become a liability that would likely cost the ANC substantial votes. Indeed, the now President of the Republic, Cyril Ramaphosa has ordered a full judicial commission of inquiry to determine the extent of this state capture. Yet, regardless of all this, and while still too early to tell decisively, it may be (somewhat ironically) that history will remember Jacob Zuma as the man who gave many South Africans access to free tertiary education, in spite of the fact that \#FeesMustFall also emerged under his leadership.
} 
major concession, students would have resumed their protests at the commencement of the 2018 academic year. However this has not been the case. Students seem content with the implementation of free education for those that qualify, and the universities themselves are also benefiting from increasing financial state support.

Overall there was a collective, pronounced failure of leadership from government and executive university management in the face of the \#FeesMustFall crisis. Arguably this was indicative of a mentality inherited from apartheid - the uninterrogated and unreflective assumption that many university students come from the (white) middle-class, and therefore that the annual increase in fees was part of necessary and unavoidable economic inflationary pressures, which would mostly be absorbed by these relatively affluent middle-class parents who pay their children's university fees. Perhaps another remnant of this mentality was the expectation on the part of government and university management that the kind of authoritarian and paternalistic attitude that permeated much of South African society under apartheid would somehow assert itself, and convince students to resume their studies. ${ }^{6}$

Instead politicians and university management were confronted (and confounded) again and again by an uncompromising refusal on the part of the protesting students to seek some kind of resolution through rational dialogue. Student leaders proved unwilling to abandon what, at the time, seemed to be impossible demands, instead engaging in a series of endless and deliberate "pseudonegotiations" (Mbembe, 2016a). These encounters (some of which I witnessed) were characterised as performative displays of, in Jansen's words, "unreason" (2017, p. 127). Characterised by aggressive, often racist hostility (and sometimes overtly patriarchal) they meant to silence any attempt by university academics or management to engage students in dialogue. It was a tactic widely used that was the deeply and deliberately antithetical to the spirit of the university.

What remains now, in the spirit of Nietzsche's idea of the philosopher as cultural physician, is a "study of the symptoms of the age" (1990, p. 75), an attempt to make some diagnoses of, and provide an explanation for these events, and to give some account of what the 'decolonised' university might mean.

\section{Epistemic and economic (de)colonisation}

\#FeesMustFall centred around two complex and interrelated issues which are succinctly expressed in the caption above: "free, decolonised education for black people." While it is tempting to suggest that the issue was purely an economic one (the question of free education, triggered by the steady, yearly increase in university fees), the ideological implications of this increase became apparent. I argue that the \#FeesMustFall movement, from this ideological position, became a tangible manifestation of, and, to some extent resistance to what Grosfoguel calls "global coloniality," in two specific senses (2011, p. 13). The students' central demand for "free decolonised education" draws on two elements of what Grosfoguel names the "colonial power matrix," namely 1) economic and 2) epistemic oppression. I suggest that what contributed the most to \#FeesMustFall and its galvanization for the decolonisation of the university as an institution is the first of these and, though the second is often conflated with it, it is a different issue.

Grosfoguel's claim, essentially, is that the idea of the 'postcolonial' world is a myth, and that the "heterogeneous and multiple global structures put in place over a period of 450 years did not evaporate with the juridical-political decolonization of the periphery over the past 50 years. We continue to live under the same 'colonial power matrix'. With juridical-political decolonization, we moved from a period of 'global colonialism' to the current period of 'global coloniality'" (p. 13).

Mbembe's definition of the "postcolony" (1992) (2001) here is also helpful in further developing Grosfoguel's claims. The "postcolony" is a fluid spatial and temporal site of emergence of what remains, and what is reconstituted after colonisation. For Mbembe it is both an "entanglement" with, and simultaneously a "displacement" of the structures of colonial power (2001, p. 14). However, it also acknowledges that there was once a "before" with the result that the postcolony is "in reality a combinations of several temporalities" (2001, p. 15). These temporalities overlap, creating a "multiplicity of times" which is "chaotically pluralistic" (2001, pp. 15, 102).

The hegemonic structures of global colonialism, and its resulting condition, global coloniality, have created a postcolonial subject both entangled with, yet displaced from those past centres of colonial power which structure this subject's current lifeworld. The "colonial power matrix" remains actively in force because those "heterogeneous and multiple global structures" (Grosfoguel, 2011, p. 13) of the colonial enterprise have deeply and permanently shaped the postcolony mentality, and continue necessarily to do so. The result is a marginalised, schizophrenic postcolonial subject attempting to negotiate multiple and overlapping identities and temporalities, yet bound firmly by, and within, the strictures of global coloniality. Thus, while Mbembe claims that the postcolony is a site of multiplicity and plurality what underpins this are still those "corporate institutions and a political machinery that ... constitute a distinctive regime of violence" (2001, p. 102). This regime is possible because all postcolonies remain, in Gramsci's sense, caught in an ongoing "passive revolution" stymied by this intractable power matrix. He warned that "no social formation disappears as long as the productive forces which have developed in it still find room for further forward movement" (2000, p. 263). Gramsci's point reinforces Grosfoguel's claim.

This regime of violence is primarily of an epistemic nature, and the university is one of those sites where it is most tangibly visible, but also, paradoxically invisible. The \#FeesMustFall protests are indicative of how internalised this schizophrenic postcolonial identity has become, and how epistemic violence functions within global coloniality. Students used public violence directed at the university as a vulnerable, physical public space, and with this violence realised the economic aim of the protests. Yet, once this aim was achieved, they willingly returned and submitted themselves to the necessary epistemic violence that structures and dictates hegemonic global coloniality. Granting free education does not mean that this education is now decolonised, or that the project of

\footnotetext{
${ }^{6}$ For some discussion on apartheid paternalism see Atkinson (2009) and “The doctrine of apartheid (1948).
} 
decoloniality is being pursued in earnest. Indeed, part of the deep and lingering problem of decoloniality is that no one is entirely sure what it is, and how it should look - an issue I will address in more detail below. ${ }^{7}$ The students' resuming their studies is a tacit, and indeed, unconscious endorsement of the power of global coloniality, acceptance of the reality that a university education grants the economic and social recognition that allows an individual to more successfully negotiate global neo-coloniality. Thus, necessarily, the postcolonial subject must subjugate themselves to ongoing epistemic violence in order to gain recognition, and the end of their economic marginalisation. Ironically, removing the economic barriers to a university education will likely create a greater surge of postcolonial subjects all too willing and motivated to submit themselves to the homogenising, epistemic violence of the university, to secure decent, meaningful employment, and the chance of a better life. This desire for a better life is thus a significant part of what not only provoked, but also ended the protests.

Indeed, Africa as a continent suffers the universal presence of ongoing economic colonisation, in the form of Western neo-liberal capitalism, which constitutes a neo-colonialism. The African continent is united with the rest of the world in terms of the flow of goods and capital, and the commodification of everyday life in terms of labour and exchange value. Unfortunate in this flow is the blunt fact that very little of Africa's immense mineral and natural wealth directly improves the lives of the majority of Africans. We are arguably the richest continent with the poorest population (Anyangwe, 2017; Shaban, 2017). Part of the dominance of economic capitalism is its homogenising power in terms of shaping and ensuring conformity of aspirations and wants across diverse peoples. Multinational companies ensure a standard, easily recognisable global footprint which can traverse continents, languages, and ethnic, racial and religious divisions. Universities are also in the grip of this dominance, chasing quantifiable measures of global success in the form of research outputs and global rankings, and being particularly attentive to the management and promulgation of their own "brand" (Gibson, 2015; Rensburg, 2017). Universities in Africa are also the deliverers of economic emancipation, with the attainment of a degree being seen as vital for improving quality of life. Global coloniality entails the ongoing homogenising and commodification of the postcolony.

The situation in post-apartheid South Africa as a postcolony in its relation to "global coloniality" is even more complicated than that of many other previously colonised countries, given the powerful remnants of apartheid structures and practices which still permeate and inform our current society. Perhaps helpful is to frame the nature of post-apartheid South African as a choice between two competing political approaches, what Wolff refers to as the "Mandela paradigm" and the "Biko paradigm" (2016, p. 444). ${ }^{8}$ The Mandela paradigm can be characterised as mediated settlement with the white oppressors, and represents a moral victory in terms of the peaceful, non-violent transfer of power. The reconciliation and non-racialism championed by this approach is epitomised in the 1996 South African Constitution. The Biko paradigm is less conciliatory, seeing the "negotiated settlements" of the 1990s as only an intermediate step towards the full liberation of black people (2016, p. 444). Mandela's post-apartheid South Africa, seen from this position, is a political subterfuge for continuing white privilege in various guises, with the Constitution ensuring its protection through law. Biko was much more ambivalent than Mandela about the role white people would play in South Africa after apartheid. While he did not want them to leave he indicated that their contribution would be proportional and on "terms laid down by blacks" ([1978] 1996, p. 121).

Arguably what has asserted itself strongly over the last few years in South Africa, by the protesting students, is an attitude towards the university which fits far more within the Biko paradigm, articulating a sense of betrayal directed at their parents' generation, as well as the current government who perhaps, too readily accepted the Mandela compromise, and with it, the dictates of global capitalism. The ever-increasing university fees served as a catalyst to express the creeping disillusionment of a post-apartheid generation who still face the same poverty, alienation and marginalisation now that the apartheid government systematically enforced in the past. It was also evident that many individuals not involved in the current protests, in fact some detrimentally affected by it (such as many lecturers) expressed sympathy with dimensions of it, recognising that expecting poor students - whose parents and grandparents were (and still are) systematically impoverished by apartheid - to pay unaffordable and increasing tertiary fees is unjust. $^{9}$

While the colonial struggle in general succeeded in freeing the enslaved, oppressed body of the African, what has lingered is a postcolonial mentality, and the practices associated with it, still bound and shaped by discourses of Western normalisation (O'Brien, 2001). Indeed, in the words of Biko, the "most potent weapon in the hands of the oppressor is the mind of the oppressed" ([1978] 1996, p. 92). In South Africa particularly, a central part of this sense of generational betrayal, and ongoing struggle to reclaim transformed identities is the growing recognition that the "radical democracy" hoped for in the political transition of the 1990s has not been realised. As O'Brien puts it, the "expressive culture" that would ideally spring from, and transcend, "ballot box democracy, parliamentary representation, liberal capitalism, cultural pluralism, and the Enlightenment discourse of rights" has not come to pass (2001, p. 3). Instead the anti-colonial struggle has produced a "neocolonial conditions" (Pechey, 1994, p. 153). The practices O'Brien mentions above, used in distorted form as tools of oppression during apartheid, have become normalised in post-apartheid South Africa without being interrogated. This outcome has, ironically, preserved the structural inequality created by apartheid economics, and been entrenched further by neo-liberal capitalism, which exacerbates the continued racial distribution of this inequality.

In terms of "free" education it is evident that \#FeesMustFall has been successful, indeed more successful than many could have anticipated. The protests drew attention to the systematic way the South African government has been underfunding universities,

\footnotetext{
${ }^{7}$ Confirming this uncertainty about 'decolonisation' Jansen (2017) gives an account of at least six possible ways of defining it.

${ }^{8}$ Bantu Steve Biko (1946-1977) was a South Africa anti-apartheid activist and a central voice in the Black Consciousness Movement. He was severely beaten by the South African apartheid security forces and died soon after.

${ }^{9}$ For example, see du Preez (2016) and Habib (2016), Vice-Chancellor of the University of the Witwatersrand during the \#FeesMustFall protests.
} 
which has been compounded significantly by a substantial increase in enrolments (Chipkin, 2016; Vermeulen, 2016). However, this solution remains part of the "Mandela" paradigm, in a sense an economic compromise, while Biko rooted his approach in non-white stream epistemes and lifeworlds, and the assertion of "Black Consciousness". This more radical position has not been realised. The section that follows will theorise some conceptual and pragmatic difficulties which contributed to this failure.

\section{4. "Decolonised" education}

The question of decolonised education and a decolonised university in South Africa remains unresolved and, arguably, unresolvable. If we accept Grosfoguel's claim of the persistence and entrenchment of "global coloniality" then the postcolony will remain necessarily and unavoidably entangled within the structures and remnants of its colonial history, one of which is the university. This places African universities in a double bind. On the one hand, they are confronted by significant pressure to conform with their international counterparts, ensuring global homogeneity of institutional structure and practice. On the other, African universities are experiencing a burgeoning desire to reclaim, and also reimagine African identities able to foster and maintain their own particular worldviews and histories, despite this global pressure (Maringe \& Ojo, 2017). Herein lies an important ongoing structural paradox: the universities, which are doing much of the work of questioning and reclaiming identities that genuinely reflect the African lifeworld, are themselves remnants of colonial culture. Another irony is that students' exposure to university, and the critical thinking skills and challenging ideas that they encounter there has undoubted emancipatory value, and contribute significantly to their ability to realise their own historical situatedness, and recognise that they do not live in a just society. An important factor in this increasing conscientisation of the student body is the efforts of most South African universities to actively re-shape their curriculums to better reflect a broader range of ideas which go beyond the Western canon. ${ }^{10}$

How should the decolonised university be thought of, then? Wolff provides a thought-provoking reductio ad absurdum: "How can one decolonise the university without keeping in mind that the university as we know it is itself part of the colonial heritage? Strictly speaking, 'decolonising' the university requires doing away with universities. Likewise, to decolonise a curriculum does then not mean to replace Western philosophical content with African philosophical content, because the entire social-institutional construction of curricula is part of the colonial heritage. Decolonising curricula would mean abolishing curricula and reinstitutionalising non-university practices of education in their place. Thus far, I have not heard anybody making a case for decolonising universities and curricula in this sense even if this is precisely what a radical critique of (neo)colonisation ultimately amounts to" (2016, p. 453).

In effect, as Wolff points out, "decolonisation cannot be exhaustively practiced" because to do so implies a logical conclusion which is untenable (2016, p. 453). Such extreme 'decolonisation' is even hypocritical and inauthentic, for it implies trying to deny, or somehow erase the history which is already ours. ${ }^{11}$ This is partly why such a radical position is nowhere seriously advocated, to my knowledge. Wolff's reductio does suggest a very important insight however; the reason why the logical possibility of a 'decolonised university' is never raised is the postcolony's ongoing entanglement with global coloniality. The idea of a 'university' that is not based on the Humboldtian, Enlightenment model has not been thought because this "hegemonic notion of knowledge production ... has set up interpretive frameworks that make it difficult to think outside these frames" (Mbembe, 2016b, p. 33).

Where now then? One possible way to think the decolonised university and African education generally suggested by Dei (2008) requires, using Kuhnian language (1996), a paradigm shift. Dei argues that education in Africa is in a "crisis" rooted in a colonial legacy of educational policies and practices that have "failed to speak adequately to the variety of human experience or to the diverse histories that shape human growth and development" (p. 233). African governments are also responsible for this crisis because of their complacency in allowing colonial educational practices and policies to persist in a context and lifeworld which they do not reflect. Thus African education remains in the grip of "dominant paradigms" that require "counter-theoretical perspectives of education" which more meaningfully reflect the African experience (2008, p. 231). Dei's position, which is echoed by other theorists such as Waghid (2014), is the rehabilitation and revival of African indigenous knowledge systems, which are "anchored in cultural experience and historical cultural knowledge" that reflect African lived experience (2008, p. 245). To resist the epistemic violence caused by the "European dominance of what constitutes valid and acceptable knowledge" Dei proposes an anti-colonial approach to reforming education which begins by gaining a genuine understanding of the indigenous practices and beliefs that shape and inform African knowledge epistemes, and transforming these into policy and curriculum praxis which speaks "to the African human condition" (2008, pp. 240, 243).

However, Dei's method for overcoming one dimension of the colonial power matrix runs aground in the other. This is that a "global restructuring of higher education is taking place [which is] related to the dynamics of global capitalism" (Mbembe, 2016b, p. 37). The dynamics of global capitalism have created "an entirely new governing rationality through which everything is "economized"' (2016b, p. 39). The university classroom and the university itself are increasingly palpable representations of this 'economising'. They function according to a clear sense of strictures in terms of what is, and what is not permissible within this framework. For example, the focus is not on knowledge for its own sake, or the advancement of the life of the mind, but bureaucratic technocracy, throughput and marketable skills - if something cannot be quantified in some way then it has no value. The mania for assessment, evaluation and

\footnotetext{
10 Jansen (2017) details many significant changes to curricula - some which began in the 1990s.

${ }^{11}$ I mean this idea of "ours" in the strongest sense of the South African Constitution which states that "South Africa belongs to all who live in it" (1996, p. 1). Given our long complex history the notion that whites or Indians are still 'settlers' and 'colonisers,' and therefore foreigners to South Africa is incongruous. Jansen (2017) makes a similar point.
} 
measurable outputs has reduced academics to 'knowledge workers' in a capitalist society, hobbled by managerialism, whose aim is to ensure that the student-customer is always satisfied with the service they receive. Our universities have become unconsciously and unreflectively enframed by the dictates of global coloniality, run "in accordance with business principles" (2016b, p. 31).

Thus, the kind of radical anti-colonial project Dei proposes may inadvertently perpetuate and disempower the postcolonial subject further, by deepening epistemic and economic marginalisation, and therefore increasing his/her greater global, passive dependence. For Mbembe this global restructuring is creating a "new imaginary of the university" expressed in terms of "transnationalization" which allows an educated, elite and mobilised labour force to traverse national boundaries, with easily transferable skills, to further international collaborations (2016b, p. 37). However, what underlies these skills and the global mobility they permit serves the "structural interests of transnationally mobile capital" (2016b, p. 37). This new era of transnationalization is one of "open global competition," and with this comes "zoning." Zoning is "what happens to the losers in the unfolding global competition" (2016b, p. 38). A radically 'decolonised' university may find itself relegated to irrelevance, because it does not produce graduates whose degrees have international recognition, and who are not equipped with those 'transferable skills' necessary for the global workplace.

Mbembe's argument suggests it is necessary to temper the kind of radical revision of African education advocated by Dei with pragmatism. In fact Mbembe articulates a position which is often elided in this current discussion about decolonisation, namely that it itself is a concept inherited "from an entirely different age and epoch" (2016b, p. 32). We see the force of the term in the work of, for example, Fanon, [(1961)] (1963), and later in Ngugi wa Thiongo'o (1986), but Mbembe wonders whether this particular concept, in the sense it was used then, is even suitable for the "complexly mutating entity" of coloniality we are fighting now (2016b, p. 32). He proposes recognising and harnessing the potential that globalisation offers in terms of the "knowledge diasporas" it creates. To do this requires thinking beyond South African-centric and African-centric terms and, instead, recognising that globalisation entails deterritorialisation - that knowledge is not bound to particular nation states but is, in Deleuze and Guattari's sense, nomadic (1987). Decolonisation for Mbembe involves "build[ing] new diasporic intellectual networks and harness[ing] the floating resources freed by the process of globalized talent mobility nomadic (2016b, p. 41).

Genuine decolonisation is thus resistant to narrow, essentialist and isolatory practices. ${ }^{12}$ It cannot be retrogressive "nativism" (Jansen, 2017, p. 167), but requires an active reckoning with the forces of globalisation. Offering South Africa's poor majority the opportunity to access free tertiary education, and ensuring that education meets, and indeed, surpasses international standards is one pragmatic way to acknowledge the power of, but also actively engage and level with, global coloniality. What this requires to some degree is the acceptance of the Humboldtian, Enlightenment university in the global South. However, this does not necessarily mean the Southern university must exactly replicate its European or American counterparts in terms of institutional culture, practice and curriculum. What is required is a re-centring, Africanisation. ${ }^{13}$ This fundamental "re-centring" of the university begins with a focus on African consciousness and lifeworlds (Mbembe, 2016b, p. 35).

One simply practical example: university iconography should not constantly remind black students that they are trespassing on a white, colonial space (Mbembe, 2016b,pp. 30-1). Indeed, not only should access be a priority, which, from an economic position many in South Africa now have, but they should, in Heidegger's sense (2001), feel that they can $d w e l l$ in the university space and feel 'at home' there, a sense of belonging, despite the mostly apartheid and colonial heritage architecture of many of South Africa's university campuses. Hence the importance of a gesture as simple as renaming buildings, and removing statues of apartheid and colonial figures whose presence on campuses serves to remind black South Africans of how they were systematically brutalised for generations. The South African university must actively work to resolve what is a complex and constantly changing balancing act. It must "engage with and reflect the identity of the society it is supposed to serve, and the knowledge it generates should be relevant and responsive to the needs of the people. It should primarily be a site for the production and distribution of new knowledge in the context of the African experience, alongside the global experience" (Ndofirepi \& Cross, 2017, p. 49).

This requires ongoing praxis, rather than mere theory, to realise a genuine African sense of dwelling in the university context, while remaining transnationally adaptive and relevant. Thus, to conclude this paper has argued that the \#FeesMustFall movement was motivated by the desire for free, and decolonised education. While the issue of free education for many students has been realised, the question of the decolonisation of the university is more elusive and difficult. The reason for this centres around the hegemonic structures and demands of global coloniality, and how these forces, to a large extent, dictate the epistemic nature of the university in the global South. What is required is a more pragmatic and imaginative response to these forces to genuinely foster "African universities, rather than universities in Africa" (Moahi, 2012, p. 548).

\section{Acknowledgements}

I would like to gratefully acknowledge the Philosophy of Education Society of Great Britain for hosting the 2017 "New Researchers in Philosophy of Education" seminar from which this paper developed. Special thanks to Alison Mackenzie, Judith Suissa and Murray Roberts for their efforts in facilitating what was a very welcoming, stimulating and enjoyable seminar. I would also like to thank the anonymous reviewers for their helpful comments. Lastly I would like to acknowledge and thank my colleagues, Louis Botha for the corridor discussions, and especially Maria Prozesky for her insightful critique and meticulous editing.

\footnotetext{
${ }^{12}$ For example, the University of Cape Town's Decolonial Winter School which hosted a dinner in which only "people of colour" where invited (Pitt, 2018).

${ }^{13}$ See, for example, Ngugi wa Thiongo'o (1986); Dei (2008); Waghid (2014); Mbembe (2016b) and Metz (2015) for some accounts of what shape Africanisation can take.
} 


\section{References}

Anyangwe, E. (2017, June 28). Why is Africa so poor? You asked Google - Here's the answer. Retrieved from https://www.theguardian.com/commentisfree/2017/jun/ 28/why-africa-so-poor-google www.theguardian.com.

Areff, A., \& Derrick Spies, D. (2017, December 16). BREAKING: Zuma announces free higher education for poor and working class students. Retrieved from https://www. news24.com/SouthAfrica/News/zuma-announces-free-higher-education-for-poor-and-working-class-students-20171216 www.news24.co.za.

Atkinson, D. (2009). Patriarchalism and Paternalism in South African "Native Administration" in the 1950s. May Historia, 54(1), 262-280.

Biko, S. ([1978] 1996). I Write What I Like. Randburg: Ravan Press.

Chipkin, I. (2016, October 16). \#FeesMustFall: Separating Treasury's truth from 'ultra-left' fiction. Retrieved from Daily Maverick https://www.dailymaverick.co.za/ opinionista/2016-10-16-feesmustfall-separating-treasurys-truth-from-ultra-left-fiction/?utm_medium =Social\&utm_campaign =Echobox\&utm_source=Facebook \&utm_term = Autofeed\#link_time = 1476653410 .

Constitution of the Republic of South Africa (1996). Government gazette.

Dei, G. (2008). Possibilities in African schooling and education. In D. Nombuso (Ed.). New direction in African education: Challenges and possibilities (pp. 229-248). Calgary: University of Calgary Press.

Deleuze, G., \& Guattari, F. (1987). A Thousand Plateaus: Capitalism and Schizophrenia. (B. Massumi, Trans.) Minneapolis: University of Minnesota Press.

du Preez, M. (2016, October 11). \#FeesMustFall 'No longer about fees'. Retrieved from News24: http://www.news24.com/Columnists/MaxduPreez/feesmustfall-nolonger-about-fees-20161011.

Fanon, F. ([1961] 1963). The Wretched of the Earth. (C. Farrington, Trans.) New York: Grove Press.

Gibson, N. (2015). Thinking outside the Ivory Tower: Towards a radical humanities in South Africa. In P. Tabensky, \& S. Matthews (Eds.). Being at home. Race, institutional culture and transformation at South African Higher education Institutions (pp. 184-202). Pietermaritzburg: University of KwaZulu-Natal Press.

Gramsci, A. (2000). The Gramsci Reader. Selected Writings 1916-1935. (D. Forgacs, Ed.) New York: New York University Press.

Grosfoguel, R. (2011). Decolonizing post-colonial studies and paradigms of political-economy: Transmodernity, decolonial thinking, and global coloniality. Transmodernity: Journal of Peripheral Cultural Production of the Luso-Hispanic World, 1(1), 1-37.

Habib, A. (2016, December 5). Op-Ed: The Politics of Spectacle - Reflections on the 2016 student protests. Retrieved from Daily Maverick https://www.dailymaverick.co. za/article/2016-12-05-op-ed-the-politics-of-spectacle-reflections-on-the-2016-student-protests/\#.WEUPdLJ950w.

Heher, J. (2017a). Commision of enquiry into higher education and training Pretoria Retrieved from http://www.thepresidency.gov.za/sites/default/files/Commission \%20of\%20Inquiry\%20into\%20Higher\%20Education\%20Report.pdf.

Heher, J. (2017b). Commision of inquiry into higher education and training. Executive summary Pretoria Retrieved from http://www.thepresidency.gov.za/pressstatements/release-report-commission-inquiry-feasibility-making-high-education-and-training.

Heidegger, M. (2001). Poetry, language, thought. (A. Hofstader, Trans.) New York: HarperCollins.

Jansen, J. (2017). As by fire: The end of the South Africa university. Cape Town: Tafelberg.

Kuhn, T. (1996). The structure of scientific revolutions. Chicago: University of Chicago Press.

Maringe, F., \& Ojo, E. (2017). Sustainable transformation in a rapidly globalizing and decolonising world. In F. Maringe, \& E. Ojo (Eds.). Sustainable transformation in African higher education (pp. 25-39). Rotterdam: Sense Publishers.

Mbembe, A. (1992). The banality of power and the aesthetics of vulgarity in the postcolony. Public Culture, 4(2), 1-30.

Mbembe, A. (2001). On the postcolony. Berkeley: University of California Press.

Mbembe, A. (2016a). A deadly fight in a tunnel. Retrieved from Facebook https://www.facebook.com/achille.mbembe/posts/10153926739481451.

Mbembe, A. (2016b). Decolonizing the university: New directions. Arts and Humanities in Higher Education, 15(1), 29-45.

Metz, T. (2015). Africanising institutional culture: What is possible and plausible. In P. Tabensky, \& S. Matthews (Eds.). Being at home: Race, institutional culture and transformation at South African Higher education Institutions (pp. 242-272). Pietermaritzburg: University of KwaZulu-Natal Press.

Mignolo, W. (2009). Epistemic disobedience, independent thought and decolonial freedom. Theory, Culture \& Society, 26(7-8), 159-181.

Mignolo, W. (2011). Epistemic disobedience and the decolonial option: A manifesto. Transmodernity: Journal of Peripheral Cultural Production of the Luso-Hispanic World, $1(2), 44-66$.

Moahi, K. (2012). Promoting African indigenous knowledge in the knowledge economy: Exploring the role of higher education and libraries. Aslib Proceedings, 64(5), $540-554$.

Ndofirepi, A., \& Cross, M. (2017). Knowledge as a public good: A critical gaze at the African university. In M. Cross, \& A. Ndofirepi (Eds.). Knowledge and change in African universities. Volume 1 - Current debates (pp. 41-58). Rotterdam: Sense Publishers.

Ngugi wa Thiongo'o (1986). Decolonising the mind: The politics of language in Africa literature. London: Heinemann.

Nietzsche, F. (1990). Philosophy and Truth. Selections from Nietzsche's notebooks of the early 1870s. (D. Breazeale, Ed., \& D. Breazeale, Trans.) New Jersey: Humanities Press International.

O'Brien, A. (2001). Against normalization. Writing radical democracy in South Africa. Durham: Duke University Press.

Pechey, G. (1994). Post-apartheid narratives. In F. Barker (Ed.). Colonial Discourse/Postcolonial theory (pp. 151-171). Manchester: Machester University Press.

Pitt, C. (2018, June 22). UCT dinner for people of colour only, organisers remain unapologetic. Retrieved from www.news24.com https://www.news24.com/SouthAfrica/ News/uct-dinner-for-people-of-colour-only-organisers-remain-unapologetic-20180622.

Rensburg, I. (2017). Reinventing greatness: Responding to urgent global-level responsibilities and critical university-level priorities. In M. Cross, \& A. Ndofirepi (Eds.). Knowledge and change in African universities. Volume 1 - Current debates (pp. 15-28). Rotterdam: Sense Publishers.

SABC Digital News (2016, September 19). Students planning to shutdown the Wits university. Retrieved from Youtube https://www.youtube.com/watch?v= CeO1pXzqr30.

Shaban, A. (2017, July 27). Africa' the richest continent on Earth is the poorest' - AU envoy to US. Retrieved from www.africanews.com http://www.africanews.com/ 2017/07/27/africa-the-richest-continent-on-earth-is-the-poorest-au-envoy-to-us//.

Staff, R. (2016, October 26). South African universities get an extra \$1.2 billion to improve student enrollment. Retrieved from Reuters https://www.reuters.com/article/ussafrica-budget-fees-idUSKCN12Q1KI?il=0.

The doctrine of apartheid (1948). The round table. The Commonwealth Journal of International Affairs, 39, $153-156$.

The World Bank (2018, April 19). The World Bank in South Africa. Retrieved from http://www.worldbank.org http://www.worldbank.org/en/country/southafrica/ overview.

Vermeulen, J. (2016, September 5). How the government gives South African universities less money each year. Retrieved from Mybroadband https://mybroadband.co.za/ news/general/178382-how-the-government-gives-south-african-universities-less-money-each-year.html.

Waghid, Y. (2014). African philosophy of education reconsidered. On being human. New York: Routledge.

Wolff, E. (2016). Four questions on curriculum development in contemporary South Africa. South African Journal of Philosophy, 35(4), 444-459. 